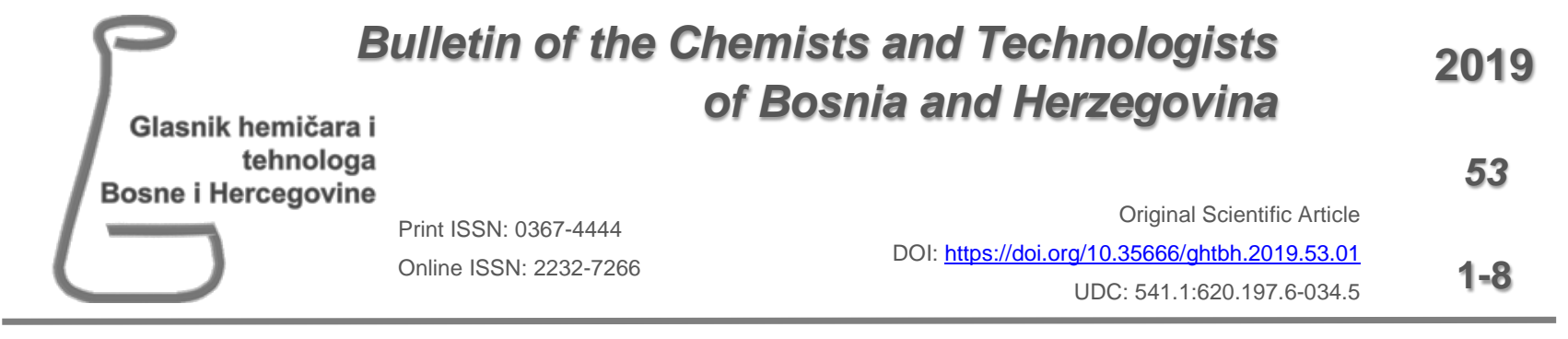

\title{
Protection of fuel filter with alkaline and acid zinc coatings
}

\author{
Šćepanović, J. a, Herenda, S. ${ }^{\text {, }}$, Korać, F. ${ }^{\text {b }}$, Vuksanović, D. ${ }^{\text {a, Radonjić, D. }}{ }^{\text {a }}$ \\ ${ }^{a}$ Faculty of Metallurgy and Technology, University of Montenegro, Cetinjski put bb, 81000 Podgorica, Montenegro \\ ${ }^{\mathrm{b}}$ Faculty of Science, Department of Chemistry, University of Sarajevo, Zmaja od Bosne 33-35, 71000 Sarajevo, B\&H
}

Article info
Received: 15/04/2019
Accepted: 17/06/2019

Keywords:

Fuel Filter

Galvanization

Electrochemistry

Corrosion

\begin{abstract}
Galvanic coatings are applied so that the surface of the base material obtains appropriate properties, corrosion resistance, durability, aesthetic appearance, and long-term application in the appropriate industry. In this paper, the aim was to protect steel fuel filters with alkaline and acid zinc coatings of different thicknesses. The coating of zinc, which is applied from the alkaline electrolyte, provides good corrosion protection with excellent coating flexibility. The thickness of the coating by the X-ray fluorescence method was tested, followed by coating tests, corrosion resistance, and electrochemical tests. The results of adhesion showed a high quality coating, as no corrosion occurred during the test. The corrosion resistance tested by the salt chamber method speaks of the appearance of white and red corrosion. On alkaline electrolyte coatings, white corrosion occurred after 168 hours of exposure to the salt test, while on white zinc samples there was a white corrosion after 240 hours of exposure. Tafel polarization diagrams have been determined: corrosion potentials, current intensities, anode and cathode Tafel coefficients and calculated corrosion rates. The active and passive corrosion zone is determined by the cyclic voltammetry.
\end{abstract}

\author{
*Corresponding author: \\ Herenda Safija \\ E-mail: \\ islamovic.safija@gmail.com
}

number of factors, and galvanic coating tests are mainly based on the metal bond with the base material (Pu et al., 2013). The most common tests are: the examination of the outer appearance of the coating, the methods for determining the coating thickness, the methods for testing the coating adhesion (adhesion) and methods for corrosion testing. Electrochemical methods are used to test the reactions and coating mechanisms, as well as the corrosion rate corrosion test (Xu et al., 2012; In this research, the polarization resistance of the unprotected sample as well as the protected samples by the linear polarization method was investigated, and polarization parameters were determined by the Tafel extrapolation method for the purpose of determining the corrosion parameters. The results of the cyclic voltammetry show the active and passive corrosion state on coatings of thickness from 5 to 15 microns. An unprotected sample has an accelerated corrosion time. 


\section{EXPERIMENTAL}

In this work, the steel covers (Delphi) of the surface area of $2.06 \mathrm{dm}^{2}$ were used, as well as steel plates measuring 7 $\mathrm{cm} \times 2 \mathrm{~cm}, 1 \mathrm{~mm}$ thick. All samples were subjected to alkaline and acidic zinc plating. The methods used to assess the quality of the coating are: coat thickness testing, coating adhesion testing (adhesion), saline test and electrochemical methods, linear polarization and cyclic voltammetry. Samples of alkaline (A) and acid (K) elecrolytes had coat thicknesses: 5, 10, 15, 20 and $25 \mu \mathrm{m}$ and one unprotected sample (N). Table 1.

Table 1. Symbols for samples

\begin{tabular}{|c|c|c|c|}
\hline Sample & Description & Sample & Description \\
\hline A5 & $\begin{array}{c}\text { Alkaline } \\
\text { electrolyte } 5 \mu \mathrm{m}\end{array}$ & K5 & $\begin{array}{c}\text { Acid electrolyte } \\
5 \mu \mathrm{m}\end{array}$ \\
\hline A10 & $\begin{array}{c}\text { Alkaline } \\
\text { electrolyte } 10 \mu \mathrm{m}\end{array}$ & K10 & $\begin{array}{c}\text { Acid electrolyte } \\
10 \mu \mathrm{m}\end{array}$ \\
\hline A15 & $\begin{array}{c}\text { Alkaline } \\
\text { electrolyte } 15 \mu \mathrm{m}\end{array}$ & K15 & $\begin{array}{c}\text { Acid electrolyte } \\
15 \mu \mathrm{m}\end{array}$ \\
\hline A20 & $\begin{array}{c}\text { Alkaline } \\
\text { electrolyte } 20 \mu \mathrm{m}\end{array}$ & K20 & $\begin{array}{c}\text { Acid electrolyte } \\
20 \mu \mathrm{m}\end{array}$ \\
\hline A25 & $\begin{array}{c}\text { Alkaline } \\
\text { electrolyte } 25 \mu \mathrm{m}\end{array}$ & K25 & $\begin{array}{c}\text { Acid electrolyte } \\
25 \mu \mathrm{m}\end{array}$ \\
\hline A51 & $\begin{array}{l}\text { Alkaline } \\
\text { electrolyte } 5 \mu \mathrm{m} \text { - } \\
\text { damaged sample }\end{array}$ & K51 & $\begin{array}{c}\text { Acid electrolyte } \\
5 \mu \mathrm{m} \text { - damaged } \\
\text { sample }\end{array}$ \\
\hline A52 & $\begin{array}{c}\text { Alkaline } \\
\text { electrolyte } 10 \\
\mu \mathrm{m} \text { - damaged } \\
\text { sample }\end{array}$ & K52 & $\begin{array}{l}\text { Acid electrolyte } \\
10 \mu \mathrm{m}- \\
\text { damaged sample }\end{array}$ \\
\hline A53 & $\begin{array}{c}\text { Alkaline } \\
\text { electrolyte } 15 \\
\mu \text { m- damaged } \\
\text { sample }\end{array}$ & K53 & $\begin{array}{l}\text { Acid electrolyte } \\
15 \mu \mathrm{m}- \\
\text { damaged sample }\end{array}$ \\
\hline $\mathbf{N}$ & $\begin{array}{l}\text { Unprotected } \\
\text { sample }\end{array}$ & & \\
\hline
\end{tabular}

\section{RESULTS AND DISCUSSION}

\section{Preparation of the sample}

Prior to the application of the protective coating, the preparation of the material was carried out in several steps: chemical degreasing, flow rinsing, bypassing, flushing, electrochemical degreasing, flushing, pickling, flushing. After preparation of the material, a protective coating is applied. The time of immersion and the intensity of the current depend on the surface of the material and the desired thickness of the coating. The electrolyte for the application of acid electrolyte coating contained a zinc concentration of 18-35 g/l, total chlorides $125 \mathrm{~g} / \mathrm{l}$, and boric acid 18-25 g/ l, a pH of 5, 25 , 5 . Coating electrolyte alkaline zinc contained a zinc concentration of 8-15 g/l, sodium hydroxide of 110-150 $\mathrm{g} / \mathrm{l}$ sodium carbonate of less than $80 \mathrm{~g} / \mathrm{l}$. After application of the protective coating, the samples were slightly grown in nitric acid, followed by the process of blue thick-layer passivation, after which the samples were silenced. An acid electrolyte is used with pure zinc anodes (purity 99.99\%), while in the alkaline electrolyte, inert steel anodes, nickel plated with $15 \mu \mathrm{m}$ semiconductor nickel at a current density of $1 \mathrm{~A} / \mathrm{dm}^{2}$, are used. Protected samples are dried for 15 minutes at a temperature of $100^{\circ} \mathrm{C}$. Figure 1-2.

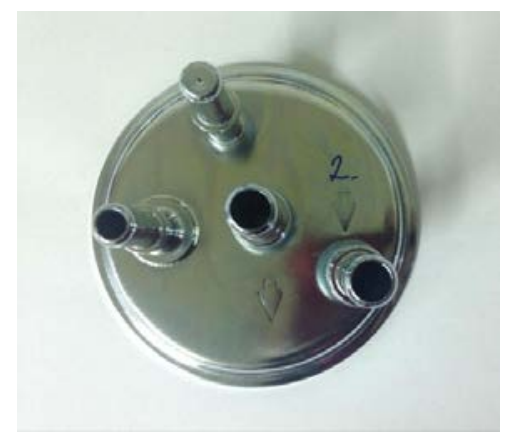

Figure 1. Acid electrolyte coating (Delphi)

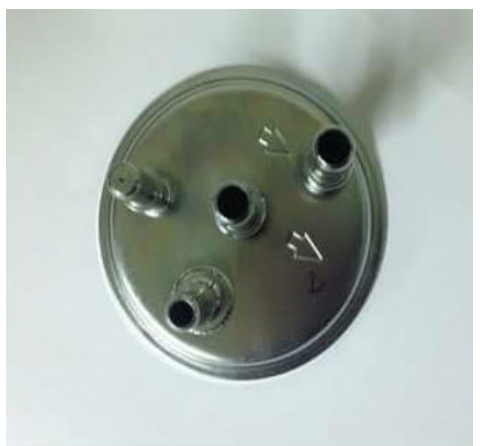

Figure 2. Alkaline electrolyte coatings (Delphi)

\section{Measurement of coating thickness}

Delphi fuel filter covers are composed of parts, which, obtained by deformation processing, are assembled into one unit together with the products obtained by machining by cutting. Such parts constituting the assembly (lid) go to the process of hard soldering and to the surface protection process. The thickness of the coating is the distance between the surface of the base material and the surface of the coating. Measurements were performed on the X-RAY instrument, and the principle of the operation of this instrument is based on the occurrence of a secondary radiation emission (fluorescence) as a consequence of electrons being triggered under the influence of the primary (incident) electron beam. The thickness of the coating was measured three times on each sample, in different places. Depending on the desired coating thickness, the retention time of the samples in the electrolyte is different. For samples subjected to alkaline zincing electrolytes for a period of 40 minutes, a thickness of $5 \mu \mathrm{m}$ was obtained, and for each subsequent increase in the thickness of the coating $(10,15,20$, and $25 \mu \mathrm{m})$, this period increased for 20 minutes. For samples subjected to acidic zincing 
electrolytes over a period of 20 minutes, a thickness of 5 $\mu \mathrm{m}$ was obtained, and for each subsequent increase in the thickness of the coating $(10,15,20$ and $25 \mu \mathrm{m})$, this period increased for 20 minutes. Table 2 shows the mean value of the coating thickness results for the alkaline and acidic sampling of the sample.

Table 2. Thickness of alkaline and acid electrolytes coating on the Delphi sample

\begin{tabular}{ccc}
\hline Sample & $\begin{array}{c}\text { Alkaline electrolytes } \\
\text { coating } \\
\boldsymbol{\mu m}\end{array}$ & $\begin{array}{c}\text { Acid electrolytes } \\
\text { coating } \\
\boldsymbol{\mu m}\end{array}$ \\
\hline $\mathbf{1 .}$ & 5,218 & 5,210 \\
$\mathbf{2 .}$ & 9,610 & 9,951 \\
$\mathbf{3 .}$ & 14,98 & 15,25 \\
$\mathbf{4 .}$ & 20,83 & 20,39 \\
$\mathbf{5 .}$ & 25,01 & 25,19 \\
\hline
\end{tabular}

With acid electrolytes for a short time, the desired thickness of the coating can be achieved, due to the rapid separation of the zinc coating, it is uneven. When obtaining galvanic coatings it is required that they have a certain thickness, which depends on their purpose. If the coatings are exposed to aggressive medium and wear, then they must be thicker than in case of lack of corrosion and wear. A thickness of $5 \mu \mathrm{m}$ is considered to be the smallest thickness needed, and a thickness of $45 \mu \mathrm{m}$ thickness of the coating that can satisfy even the most difficult conditions of exploitation. The thickness of the coating is not even on a flat surface at each location is equal, the difference in the thickness of the coating on the relief surface from place to place is even greater. Thus, these methods describe the method of determining the local and medium thickness of the coating. The local thickness refers to the thickness of the coating at a particular site, and the mean thickness is the mean value of the coating thickness over the entire surface.

\section{Coating Adhesion Testing (Adhesion)}

To test the adhesion of the coating, a heating method is used, which is based on different linear coefficients of the spreading of the base material and the coating metal, resulting in the heating of the sample at the boundary surface creating stresses that tend to separate the coating from the base material. Samples were heated in a laboratory dryer for 1 hour at a temperature of $180^{\circ} \mathrm{C}$. After heating, the samples were immersed in cold water without any change (bubbles, peeling of the coating) on the alkaline and acid electrolytes coatings, nor on the incised samples. Figure 3-6. In the unprotected sample, after submerging in cold water and drying, corrosion occurred after a few minutes. Figure 7.

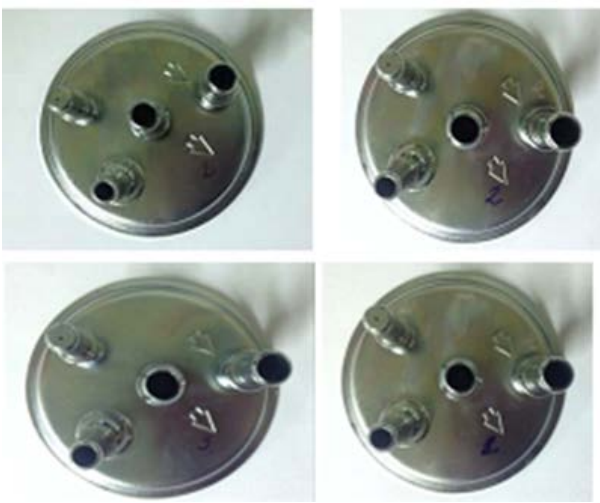

Figure 3. Sample A10 i A15 before and after

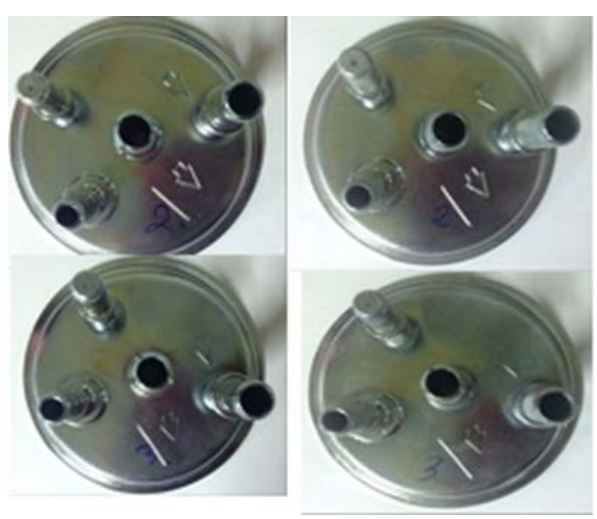

Figure 4. Sample A52 i A53 before and after the adhesion test

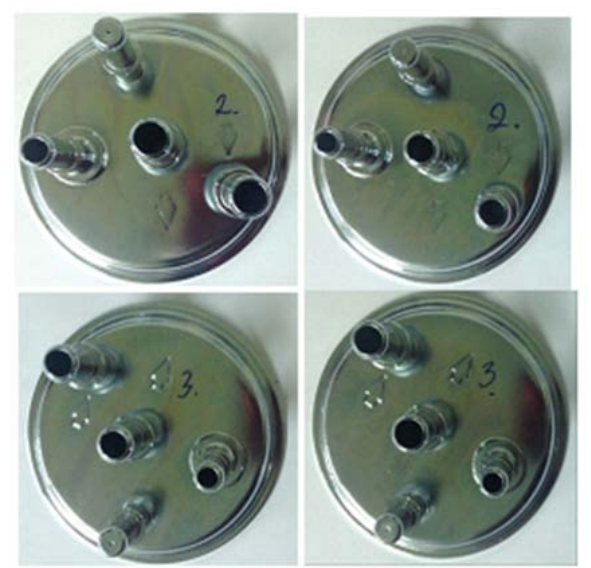

Figure 5. Sample K10 i K15 before and after

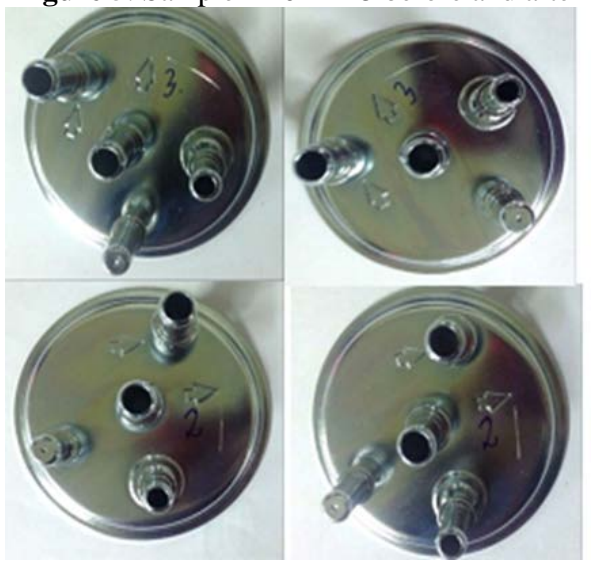

Figure 6. Sample K52 i K53 before and after the adhesion test 


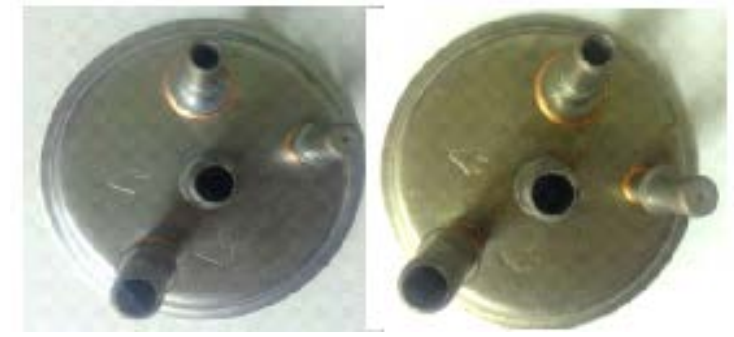

Figure 7. Unprotected sample before and after the adhesion test

Adhesion methods define the method and conditions for determining the adhesion of the coating onto the base material. It is very important that in the electrolytic deposition of metal coatings firmly bind to the base material, so as not to partially or completely peel off. The poor bonding of the coating to the substrate occurs when the surface is not well prepared, the fat or oxide layer is not completely removed. If it is known that metal coatings do not have good adhesion to the substrate, they are deposited on the intermediate layer, most commonly copper, which is well bonded to all metals and for which all coatings are well grown. There is no method for determining the value of adhesion that would yield quantitative results, but by different methods it can be determined only if adhesion is satisfactory or not.

\section{Corrosion testing}

The test method in the salt chamber was used for corrosion testing. It is a standard test method used to test the metal resistance to corrosion. In the saline chamber, the samples were exposed to the fog of sodium chloride solution (3-5\%) at a temperature $\left(35 \pm 2{ }^{\circ} \mathrm{C}\right)$. Upon completion of the test, the samples are carefully removed from the exposure zone, a mild jet of running water is washed, or in a water not higher than $40^{\circ} \mathrm{C}$, to remove it deposited on the examined surface. Then the samples are dried (compressed air). Products obtained by testing in the salt chamber are hydroxides and oxides of metal, which protects the base material, this change has been recorded as the appearance of white corrosion and iron (III) oxide change has been recorded as a phenomenon of red corrosion. Table 3 . Under atmospheric conditions, the first product of the corrosion is the metal hydroxide, which protects the base material. For example, if the zinc surface if exposed to a humid environment (snow, rain, mist) zinc will react with water and create a corrosion product of zinc hydroxide, which is voluminous, porous and unstable. Protected material exposed to this environment, where there is the lack of oxygen and carbon dioxide, continues the reaction of the formation of zinc hydroxide and gradually spills coating. The presence of a large amount of zinc hydroxide prevents the formation of a stable zinc carbonate product, which is passive to environmental influences.

In Table 3, we can notice that samples of alkaline and acid electrolytes (A5 and K5) that were longer in the saline chamber, have almost the same thickness of the coating, which is expected because they are samples in which the coating is not cut and that it is necessary longer time to appear iron (III) oxide. The damaged samples, keept in both alkaline and acidic electrolytes, were submerged the same number of hours in the salt chamber until the appearance of white corrosion.

Table 3. Results of white and red corrosion for alkaline and acid electrolytes

\begin{tabular}{|c|c|c|c|}
\hline 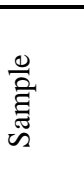 & 品兽总 & 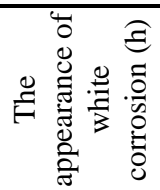 & 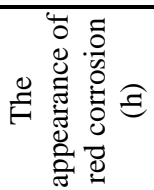 \\
\hline A5 & 5,20 & 240 & 936 \\
\hline A51 & 5,40 & 240 & 768 \\
\hline K5 & 5,47 & 168 & 720 \\
\hline K51 & 5,30 & 168 & 648 \\
\hline
\end{tabular}

This is expected, since both samples were passivated in the same passivation and silenced under the same conditions. In the case of the damaged sample, the electrochemical process and the oxidation of zinc occurred, which further protects the basic construction material.

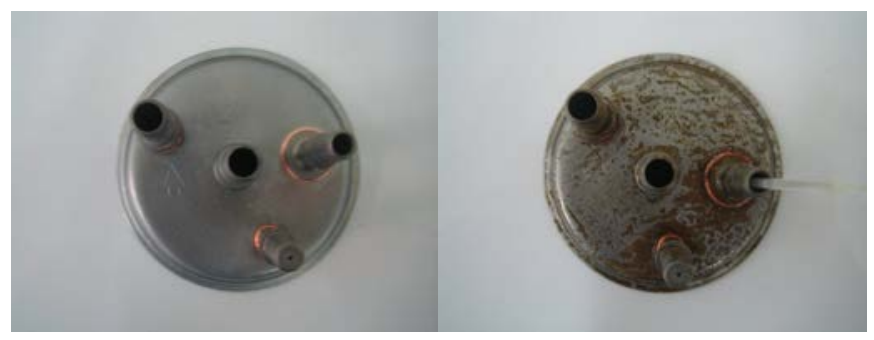

Figure 8. The results of the salted chamber of the unprotected sample

In Figure 8, we see that red corrosion has occurred on the unprotected sample, the formation of iron (III) oxide already after 24 hours.

\section{Electrochemical testing of corrosion}

The electrochemical test was carried out on the device potentiostat/galvanostat $263 \mathrm{~A}$ and the lock-in amplifier 5210 by Princeton Applied Research and using the software Power CV. The system consisted of three electrodes: working electrodes, reference $\mathrm{Ag} / \mathrm{AgCl}$ and platinum electrodes, and all the shots were performed in 3\% sodium chloride, linear polarization and cyclic voltammetry within the various limits of the potential of 1.2 to $1 \mathrm{~V}$, with the previous stabilization of the systempotentials in time 2h. Figure 9 shows the linear polarization method for alkaline electrolyte of different thicknesses of the coating, as well as the galvanized sample. In Table 4 we see the values of the corrosion rate for different thicknesses. The maximum corrosion rate is at a thickness of 5 microns. Under the conditions examined, we received the lowest corrosion rate at a layer thickness of 15 microns in the alkaline electrolyte. We conclude that the reason is the mass transport that is of primary importance for the rate of corrosion in environments with limited cathode reactant. The maximum corrosion rate in such a situation is given by 
the limiting current density of the cathodic reactant to the surface. When we compare the values of the corrosion current and the corrosion rate in Tables 4 and 5, we see that there are higher values for the thickness of the alkaline coating of 5 microns. We assume that the chemical composition of the electrolyte is caused the high alkaline conditions result in the formation of a rough coating. The figure10 shows the results obtained by the linear polarization method for acid electrolyte of different thicknesses of the coating as well as the frozen zinc sample. In both diagrams we see that the corrosion potential of the $5 \mu \mathrm{m}$ coating is the highest in comparison with other coatings. Also in the alkaline coating of $10 \mu \mathrm{m}$ thick in the anodic region of the potential, we can see the appearance of a passive, as well as the appearance of a transpasive form, with a polarization resistance value of $5737 \Omega$. As the thickness of the coating grows, the polarization resistance of the test sample increases.

Anode passivation and transpasition were detected on all thicknesses (5-25 $\mu \mathrm{m})$. Also, in the case of alkaline and acidic galvanizing, the production of white corrosion that is easily deposited on the surface of the sample due to the high electrochemical reactivity of zinc, as confirmed by the work of the author An, et al., 2017.

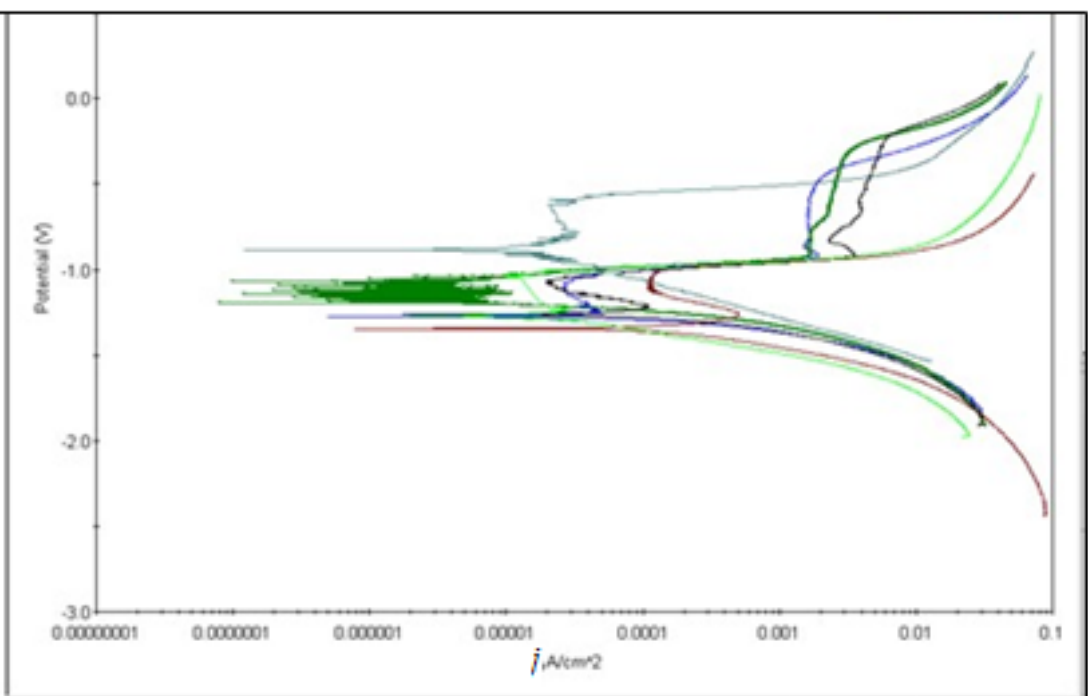

Figure 9. Polarization curve for the sample of alkaline electrolytes filters of different thicknesses: $-5 ;-10 ;-15 ;-20 ;-25 \mu \mathrm{m}$; — damaged sample $5 \mu \mathrm{m}$

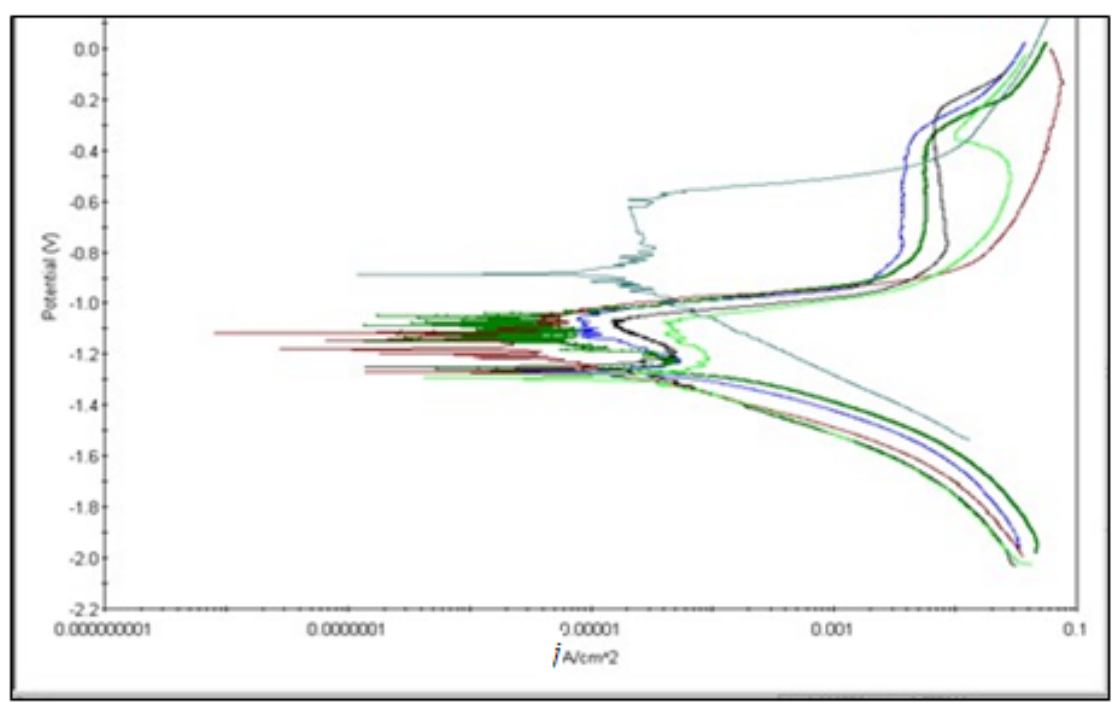

Figure 10. Polarization curve for the sample of acid electrolytes filters of different thicknesses: $-5 ;-10 ;-15 ;-20 ;-25 \mu \mathrm{m} ;$ - damaged sample $5 \mu \mathrm{m}$ 
Table 4. Electrochemical data of alkaline electrolytes filters of different thicknesses from Tafel extrapolation.

\begin{tabular}{cccccc}
\hline $\begin{array}{c}\text { Thickness } \\
(\boldsymbol{\mu m})\end{array}$ & $\begin{array}{c}\mathbf{E} \\
\mathbf{( \mathbf { m V } )}\end{array}$ & $\begin{array}{c}\mathbf{I}_{\mathbf{c o r r}} \\
\left(\boldsymbol{\mu} \mathbf{A} \mathbf{c m}^{-2}\right)\end{array}$ & $\begin{array}{c}\text { Corrosion } \\
\text { rate } \\
(\mathbf{m m p y})\end{array}$ & $\begin{array}{c}\boldsymbol{\beta}_{\mathbf{A}} \\
\left(\mathbf{m V d e c}^{-\mathbf{1}}\right)\end{array}$ & $\begin{array}{c}\boldsymbol{\beta}_{\mathbf{k}} \\
(\mathbf{m V d e c} \mathbf{- 1})\end{array}$ \\
\hline 5 & -1027 & 3.56 & 1.5 & 117 & 64 \\
10 & -1204 & 1.36 & 0.57 & 99 & 112 \\
15 & -1262 & 1.01 & 0.43 & 108 & 49 \\
20 & -1357 & 1.30 & 0.55 & 86 & 33 \\
\hline
\end{tabular}

In the acid electrolyte coating diagram 10, we see that a good sample protection is also performed, and that the same sequence of polarization resistance increases as the thickness of the coating is increased by the scanning velocity of $0.166 \mathrm{mV} / \mathrm{s}$. Table 5 . If we compare the value of corrosion rate in Table 4 and Table 5, we can conclude that it is better and more stable coating of acid electrolyte. In table 4 we see that the rate of corrosion at the same coating thickness of 10 and 20 microns. This rate of corrosion (0.11 mmpy) can be explained by simple adsorption on the electrode surface and by blocking active sites on the surface. This process takes place until the establishment of the dynamic equilibrium between the concentration of the residual solute in the solution and its concentration on the metal surface.

Table 5. Electrochemical data of acid electrolyte filters of different thicknesses from Tafel extrapolation.

\begin{tabular}{cccccc}
\hline $\begin{array}{c}\text { Thickness } \\
(\boldsymbol{\mu m})\end{array}$ & $\mathbf{E}(\mathbf{m V})$ & $\begin{array}{c}\mathbf{I}_{\mathbf{c o r r}} \\
\left(\boldsymbol{\mu} \mathbf{A c m} \mathbf{c m}^{-2}\right)\end{array}$ & $\begin{array}{c}\text { Corrosion } \\
\text { rate } \\
(\mathbf{m m p y})\end{array}$ & $\begin{array}{c}\boldsymbol{\beta}_{\mathbf{A}} \\
\left(\mathbf{m V d e c}^{-\mathbf{1}}\right)\end{array}$ & $\begin{array}{c}\boldsymbol{\beta}_{\mathbf{k}} \\
\mathbf{( m V d e c}^{-\mathbf{1}} \mathbf{)}\end{array}$ \\
\hline 5 & -1271 & 1.47 & 0.62 & 134 & 59 \\
10 & -1251 & 2.75 & 0.11 & 98 & 74 \\
15 & -1252 & 3.94 & 0.16 & 106 & 129 \\
20 & -1118 & 2.81 & 0.11 & 66 & 81 \\
25 & -1292 & 1.76 & 0.74 & 73 & 87 \\
\hline
\end{tabular}

Ponte et al., 2002 also notes the oxidation peaks of $\mathrm{Fe}^{2+}$ and $\mathrm{Fe}^{3+}$ ions in their work. In his research, the passivation potential starts at around - $950 \mathrm{mV}$, which is approximately similar in our research where we obtained the values of the potential from about $-1100 \mathrm{mV}$ to about - $1300 \mathrm{mV}$ and for the alkaline and acidic coating of the sample. Liu et al., 2013 examined the corrosion of pure zinc and zinc with different amounts of aluminum, and also obtained values of the potential of about $-1050 \mathrm{mV}$ and a small current value which proves a low sample rate in the investigated environment of sodium chloride. The mechanism of zinc behavior in the corrosion environment is described in Hosking et al:

$\mathrm{Zn}_{(\mathrm{s})} \rightarrow \mathrm{Zn}^{2+}+2 \mathrm{e}^{-}$
$\mathrm{O}_{2}+2 \mathrm{H}_{2} \mathrm{O}+4 \mathrm{e}^{-} \rightarrow 4 \mathrm{OH}^{-}($aq)

$\mathrm{Zn}^{2+}+2 \mathrm{OH}^{-} \rightarrow \mathrm{Zn}(\mathrm{OH})_{2(\mathrm{~s})} \rightarrow \mathrm{ZnO}_{(\mathrm{s})}+\mathrm{H}_{2} \mathrm{O}$

In the first step, zinc corrosion is controlled by zinc dissolution, and the cathode reaction occurs in the second step, where the hydroxide ions are responsible for the formation of zinc hydroxides (Mahdy et al., 2013). Chloride ions migrate to anodic sites in the presence of sodium chloride. This mechanism has also been proven by cyclic voltametrium where an activation and passivation zone is observed, depending on the thickness of the coating Figure 11. 


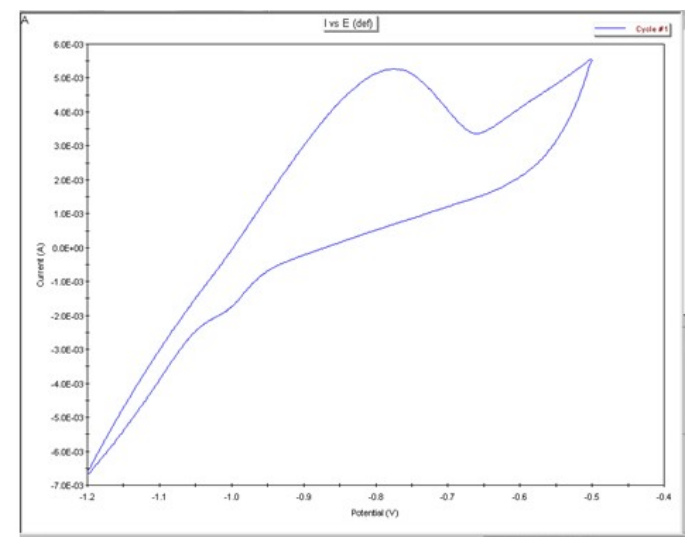

a)

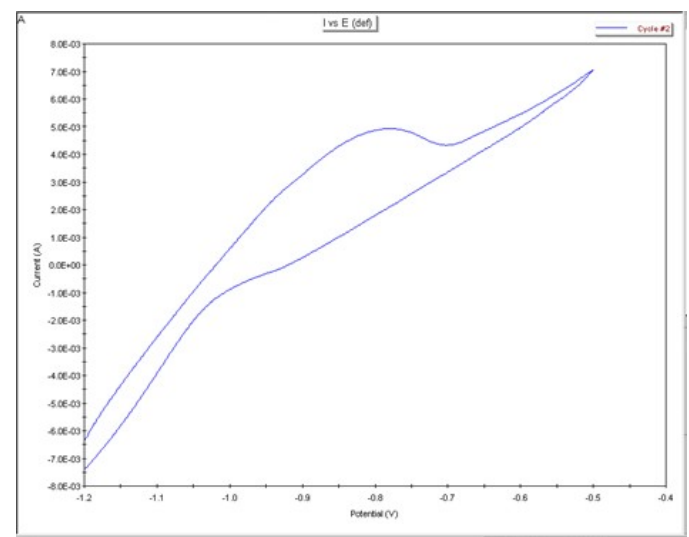

b)

Figure 11. A cyclic voltamogram of an alkaline electrolytes of different coat thicknesses as follows: a) $5 \mu \mathrm{m}$ and b) $15 \mu \mathrm{m}$

In Figure 11, we see that depending on the coating thickness, we have the formation of reduction peaks that are more pronounced with a coating thickness of 5 microns $(-0,78 \mathrm{~V})$ because the diffusion of the ions and the solubility of the zinc are facilitated. As the thickness of the coating increases, the surface area between the separation peaks, and also the corrosion current, precisely because of the migration and diffusion of the ions in the chloride environment, which confirms the previously explained mechanism. Abdel-Gawad et al. which examined the phosphate coating of steel in sodium chloride, also received a lower current density as the thickness and coating time increased.

\section{CONCLUSION}

Based on the results of the saline chamber, we can conclude:

- The time until red corrosion occurs in the alkaline electrolytes coatings, the thickness of the $5 \mu \mathrm{m}$ coating is $936 \mathrm{~h}$, while in the frozen sample the red corrosion occurred after $768 \mathrm{~h}$.

- The time before the appearance of red corrosion in an acid electrolytes sample, the thickness of the $5 \mu \mathrm{m}$ coating is after $720 \mathrm{~h}$, while in the damaged sample the red corrosion occurred after $648 \mathrm{~h}$.
- By comparing the alkaline and acid electrolytes coatings with and without damage to the coating, we can conclude that better corrosion resistance provides the protection of the alkaline electrolytes coating.

- An unprotected sample was corroded already after $24 \mathrm{~h}$. Based on electrochemical measurements we can conclude:

- Alkaline electrolyte coatings with a thickness up to 15 microns thick show oxidation and reduction peaks on cycloltamograms.

- In the case of alkaline electrolytes coatings of 20 and 25 microns, the diffusion process is difficult, and therefore the corrosion process.

- Acid electrolyte coatings also show anodic passivation and transpasification on Tafel diagrams.

- Deformed samples of alkaline electrolytes, as well as acid electrolytes coatings with a thickness of 5 microns show the tendency of corrosive formation on the surface of the material.

\section{REFERENCES}

Abdel-Gawad, S. A., Sadik, M.A., Shoeib, M.A. (2018). Enhancing Corrosion Resistance of Galvanized Steel by Phosphating and Silicate Post - Sealing. International Journal of Electrochemical Science, 13, 2688 - 2704.

An, K., An, C., Yang, C, Qing Y., Shang, Y., Liu, C. (2017). Effect of Phosphating and Post-sealing on the Corrosion Resistance of Electro - galvanized steel. International Journal of Electrochemical Science, 12, $2102-2111$.

EL-Mahdy, G.A , Dyab, A.K.F., Atta, A.M., Al-Lohedan, H.A. (2013). Influence of droplet characteristics on the electrochemical behavior of Zinc. International Journal of Electrochemical Science, 8, 9992 - 10000.

Hosking, N.C., Hosking, M.A., Shipway, P.H., Rudd, C.D. (2007). Corrosion resistance of zinc-magnesium coated steel. Corrosion Science, 49, 3669-3695.

Liu, Y., Li, H., Li,Z. (2013). EIS Investigation and Structural Characterization of Different Hot-Dipped Zinc-Based Coatings in $3.5 \% \mathrm{NaCl}$ Solution. International Journal of Electrochemical Science, 8, 7753 - 7767.

Parvini Ahmadi, N., Rafiezadeh E. (2009). Effect of Aluminum on Microstructure and Thickness of Galvanized Layers on Low Carbon silicon-Free Steel, International Journal of Iron \& Steel Society of Iran, 6, 25.

Pontea, H.A., Maula, A.M., Alvarengab, E. A. (2002). Analysis of Electrochemical Porosity of Phosphatized Coatings on Galvanized Steel Substrate. Materials Research, 5 (4), 439-446.

Pu, Z., Wang, Q.F., Shuai, M.B., Lang, D.M. (2013). Galvanic Corrosion between Depleted Uranium and 40Cr Steel. International Journal of Electrochemical Science, 8, 991-1001.

Vourlias, G., Pistofidis, N., Chaliampalias, D., Pavlidou, E., Patsalas, P., Stergioudis, G., Tsipas D., Polychroniadis, E.K. (2006). A comparative study of the structure and the corrosion behavior of zinc coatings deposited with various methods. Surface and Coatings Technology, 200, 6594. 
Xu, J., Sun, C., Yan, M.C., Wang, F.H. (2012). Effects of Sulfate Reducing Bacteria on Corrosion of Carbon Steel Q235 in Soil-Extract Solution. International Journal of Electrochemical Science. 7, 11281-11296.

Zand, R.Z, Verbeken, K., Adriaens, A. (2013). Influence of the Cerium Concentration on the Corrosion Performance of Ce-doped Silica Hybrid Coatings on Hot Dip Galvanized Steel Substrates. International Journal of Electrochemical Science, 8, 548-563.
Zandi Zand, R., Verbeken, K., Adriaens, A. (2012). Electrochemical Assessment of the Self-Healing Properties of Cerium Doped Sol-Gel Coatings on 304L Stainless Steel Substrates. International Journal of Electrochemical Science, 7, 9592-9608.

Zhang, X.G. (1996). Corrosion and Electrochemistry of Zinc, Plenum Press, NewYork

\section{Summary/Sažetak}

Upotreba prevlaka na bazi cinka za zaštitu od korozije čeličnih podloga je veoma široko rasprostranjena. Galvanske prevlake se nanose da bi površina osnovnog materijala dobila odgovarajuća svojstva, otpornost prema koroziji, postojanost, estetski izgled, kao i dugotrajnu primjenu u odgovarajućoj industriji. U ovom radu cilj je bio zaštititi čelične filtere goriva sa alkalnim i kiselim prevlakama cinka različitih debljina. Prevlaka cinka koja se nanosi iz alkalnog elektrolita, pruža dobru zaštitu od korozije uz odličnu savitljivost prevlake. Ispitana je debljina prevlake metodom rendgenske fluorescencije, nakon toga vršena su ispitivanja prijanjanja prevlake, te korozione postojanosti, kao i elektrohemijska ispitivanja. Rezultati adhezije su pokazali visok kvalitet prevlake, jer ni na jednom uzorku tokom ispitivanja nije došlo do pojave korozije. Koroziona postojanost ispitana metodom slane komore govori o pojavi bijele i crvene korozije. Na uzorcima kiselog cinka, došlo je do pojave bijele korozije nakon 168 h izloženosti slanoj komori, dok je na uzorcima alkalnog cinka došlo do pojave bijele korozije nakon 240 h izloženosti. Tafelovim polarizacionim dijagramima su određeni korozioni potencali i struje korozije te izračunate brzine korozije. Cikličnom voltametrijom je određeno aktivno i pasivno područje korozije (oksidacioni redukcioni pikovi) u području potencijala od -1.2 do $1 \mathrm{~V}$. Najveću brzinu korozije pokazao je uzorak alkalnog cinka od 5 mikrona, jer je najmanja prevlaka. Dok kod kiselog cinak najveća brzina korozije je kod debljine prevlake od 25 mikrona. 